\title{
Islamic Social Finance and the impact of the Covid-19 pandemic
}

\author{
Nasim Shah Shirazi ${ }^{1}$, Laura Aibolovna Kuanova ${ }^{2}$, Aziza Serikovna Zhuparova ${ }^{2}$ \\ ${ }^{1}$ Hamad Bin Khalifa university, ${ }^{2}$ Al-Farabi Kazakh national university
}

\begin{abstract}
This paper aims to examine the spread of social tools of Islamic finance before and after the Covid-19 pandemic in Kazakhstan, as the country where Islamic finance is most promoted in the region. As a result of the absence of official and centralized information, the research has been done on an internet-based survey. The results of the research have been based on the stratified sample of 1252 respondents before and after the emergency was declared in Kazakhstan as a result of the global Covid-19 pandemic. The authors applied SPSS statistics and survey-based indicators.

The findings revealed the depth of awareness of social tools of Islamic finance, understanding of the main principles of Zakat and Sadaqah and difference of them. It was found that the age of the respondents has positive effects on the periodicity and amount of the donations. Furthermore, the results showed that the absence of a centralized system of charity in the country and the mistrust of intermediaries inhibit the development of Islamic finance instruments and lead to donations directly to needy people. The major constraints impeding Islamic social finance include the underdevelopment of Islamic finance as a value-based financial system.

Islamic social finance tools could be both a resource and a solution for solving sustainability issues during and after the pandemic period in the country. The authors identified the impact of the Covid-19 pandemic on the structure of the charity projects, on the increase of the demand for financial assistance by individuals and the income decrease of the donators.

Keywords: Islamic social finance, zakat, Covid-19 pandemic, sadaqah, waqf, charity
\end{abstract}

\section{Исламдық әлеуметтік қаржы және Covid-19 пандемиясының әсері}

\section{Түйін}

Ғылыми жұмыстың мақсаты Қазақстанда Covid-19 пандемиясына дейін және одан кейінгі уақытта Исламдық қаржының әлеуметтік құралдарының таралуы мен дамуын зерттеу болып табылады. Елде қайрымдылық мөлшері туралы ресми және орталықтандырылған ақпараттың болмауы нәтижесінде зерттеу интернет-сауалнама негізінде жүргізілді. Мақаланың нәтижелері Covid-19 жаһандық пандемиясының салдарынан елде төтенше жағдай жарияланғанға дейін және одан кейін 1252 респонденттің жауаптарынан құрылған стратификацияланған іріктемені пайдалану арқылы жасалды. Авторлар SPSS статистикасы мен сауалнама қорытындысына негізделген өлшемдерді қолданды.

Алынған қорытындылар Исламдық қаржының әлеуметтік құралдарының ерекшеліктерін, зекет пен садақаның негізгі қағидаларын және олардың айырмашылықтарын түсіну тереңдігін анықтады. Респонденттердің жасы қайырымдылықтың жиілігі мен мөлшеріне оң әсерін тигізетіні анықталды. Сонымен қатар алынған нәтижелер елде қайырымдылықтың орталықтандырылған жүйесінің болмауы және делдалдарға, яғни қайырымдылық қорларына сенімсіздік Исламдық қаржы құралдарының дамуына кедергі келтіретінін және мұқтаж адамдарға тікелей делдалсыз қайырымдылық жасауға әкелетінін көрсетті. Елдегі Исламдық әлеуметтік қаржының дамуын тежейтін мәселе Исламдық қаржының құндылыққа негізделген қаржы жүйесі ретінде қабылданбауы болып табылады.

Исламдық әлеуметтік қаржыландыру құралдары пандемия кезеңінде және одан кейінгі елдегі тұрақтылық мәселелерін шешудің ресурсы да, шешімі де болуы мүмкін. Авторлар Covid-19 пандемиясының қайырымдылық жобалар құрылымының өзгерісіне, жеке тұлғалардың қаржылық көмекке сұранысының артуына және қайырымдылық жасаушылардың кірістерінің төмендеуіне әсерін анықтады.

Түйін сөздер: Исламдық әлеуметтік қаржы, зекет, Covid-19 пандемиясы, садақа, вакф, қайырымдылық

\section{Исламские социальные финансы и влияние пандемии Covid-19}

\section{Аннотация}

Целью статьи является изучение распространения и развития социальных инструментов исламских финансов в Казахстане до и после пандемии Covid-19. В силу отсутствия в стране официальной и централизованной информации о размерах благотворительности исследование проводилось на основе интернет-анкетирования. Результаты исследования были получены с использованием стратифицированной выборки, составленной из ответов 1252 респондентов до и после объявления чрезвычайной ситуации в стране из-за глобальной пандемии Covid-19. Авторы использовали критерии, основанные на статистике SPSS и результатах опроса.

Полученные выводы выявили глубину понимания особенностей социальных инструментов исламских финансов, основные принципы зекета и садака, а также их различий. Установлено, что возраст респондентов положительно влияет на частоту и размер оказаной благотворительной помощи. Кроме того, полученные результаты показали, что отсутствие в стране централизованной системы благотворительности и недоверие к посредникам, то есть благотворительным фондам, препятствует развитию исламских финансовых инструментов и приводит к прямым пожертвованиям нуждающимся. Проблема, сдерживающая развитие исламских социальных финансов в стране, заключается в том, что исламские финансы не воспринимаются как финансовая система, основанная на ценностях. Инструменты Исламского социального финансирования 
могут быть как ресурсом, так и решением проблем устойчивого развития в стране во время и после пандемии. Авторы выявили влияние пандемии Covid-19 на структуру благотворительных проектов, увеличение спроса на финансовую помощь со стороны физических лиц и снижение доходов благотворителей.

Ключевые слова: Исламские социальные финансы, зекет, пандемия Covid-19, садака, вакф, благотворительность.

\section{Introduction}

It is a well-known fact that despite the formal overcoming global financial and economic crisis that began in 2008 , the global debt crisis continues, after passing the acute period [1]. At the time of an unfinished and lingering crisis, the outbreak of COVID-19 (SARS-COV-2) had a detrimental effect on global healthcare systems with a ripple effect on every aspect of human life [2].

In this situation, it is important to consider and develop investing systems that affect the development of a real sustainable sector of the economy in the long term.

Once considered as a paradoxical financial system, Islamic finance has shown phenomenal growth over the years. According to a Global Islamic Finance report from 2019, Islamic financial assets worldwide reached 2.591 trillion US dollars, while the rate of increase of global Islamic finance has remained at about $12.46 \%$ every year for the last 10 years [3], however, last year growth was only $2 \%$ [4].

At the same time, sustainable, responsible and impact investing, also known as socially responsible or ethical investing, has progressed about two and half times from 13.3 trillion US dollars in 2012 (first report) to 30.7 trillion US dollars at the start of 2018 [5], [6].

Social finance or impact investing is an approach to managing investments that deliver a social and environmental dividend as well as an economic return. Islamic finance can be considered a subcategory of socially responsible investing. However, there is a basic difference between the two meanings in terms of conceptual ideas: the guiding principle of Islamic finance is based on religion, while impact investing believes in the concept that returns to society should be ethical and sustainable.

Despite the difference in the guiding concepts of these investment categories, Islamic social finance can contribute towards sustainable investing as well as Islamic financial inclusion through the following fundamental principles: governing property, wealth creation and charitable distribution.

\section{A literature review: Social efficiency of Islamic Finance}

Islamic finance is socially profitable, empowering to humanity and governed by universal moral norms that preclude investing in prohibited and immoral businesses. Based on Shariah rules, Islamic finance forbids interest (Riba) in any form [7], a norm that is absolute and unshakable; however, the strength of the market and the market economy are not denied [8]. This key norm of the prohibition of interest allows states that adopt Islamic finance to promote real economic development [9]. The key principles include deploying finance in service of the real economy, profit and loss sharing to structure equity partnerships, redistribution of wealth and opportunity, and risk-sharing modes of financing [10]. These principles are strongly interconnected and complement each other in the development of the real economic validity that creates new wealth. Islamic finance also promotes socioeconomic empowerment using social tools - Zakat (alms-giving), Waqf (endowment) and Sadaqah (voluntary) - which have been adopted and applied even outside the Islamic world. All these tools of Islamic social finance are associated with philanthropic giving but have different forms and definitions [11]. Zakat is an obligatory and mandatory payment of income, whereas Waqf refers to charitable giving as a charitable endowment trust [12]. Moreover, Sadaqah has more of a charitable and voluntary nature and means giving something to the needy without the expectation of return. These instruments are used to provide education and healthcare, develop infrastructure, and maintain social welfare provisions for the poor and destitute, albeit in a mostly informal structure [13].

While the expression "Islamic social finance" has become widespread in recent years, it is a "NewOld" financial philosophy that has historically been proven to overcome social challenges [14]. Even though Islamic social finance is an emerging instrument in contemporary financial science and systems, Islamic social finance tools have been instrumental in the alleviation of poverty and socioeconomic development for over 1400 years. Its instruments can be leveraged to bridge financing gaps and create social safety nets. According to the Islamic Development Bank (IDB), zakat potential is $3 \%$ of global GDP, whereas the actual collection is $0.15 \%$ of GDP for OIC countries [15]. Some recent studies have provided different estimates of 
global zakat collection that range from 200 billion to 1 trillion US dollars. It should be noted here that these estimates vary because a huge share of zakat is paid at the individual level and is thus not reflected in official data [16]. As noted by IDB, the GDP of OIC member countries is 6 trillion US dollars, while actual zakat is estimated at 10 billion US dollars, although potential estimation reaches 200 billion US dollars [15].

Waqf plays a significant role in economic development that is a consequence of the features of social nature. The key among them are enhancing economic progress, eradicating poverty, restoring distribution of income, preventing deficit financing and reducing government expenditure [17]. According to IRTI, the potential global assets of Waqf are estimated by the World Bank as being about 550-600 billion USD dollars [18].

It is a fact that there are 167.6 million people in the world in need of humanitarian assistance, these days. The budget provided for humanitarian aid increases every year and amounted to 28.8 billion US dollars in 2019 [19]. The pandemic which had come in almost every country has influenced the situation of the need for humanitarian support and has deepened the problem. There is a real potential that Islamic finance could provide solutions.

The philosophy of Islamic finance is to protect the most important aspects of being human: life, faith, mind, wealth and progeny [20]. Islamic finance based on Islamic law, and the overarching objectives of this law are concerned with the protection of religious freedoms, family rights, the promotion of intellectual thought and reasoning, and the preservation of wealth.

Islamic finance has always advocated the narrative of risk-sharing, more equitable distribution of wealth, and fairness and justice in all transactions [21]. It also encourages entrepreneurship, promotes real economic development and supports the principles of long-term sustainability. However, Islamic finance has been criticized for converging into conventional practices. Its rapid growth has been witnessed primarily in wealthy nations, supporting the premise that the current Islamic finance system improves the lives of the wealthy without negatively impacting the less fortunate.

Islamic finance may not yet have provided an impact on socio-economic development that is in line with its lofty ideals. However, there is now an emerging trend of Islamic social finance and investments in response to the growing global demand for ethical investments [22]. It thus seems that responsible investing is profitable, even in the short-term. The consequence over the long term is significantly profitable: as the economy grows and more participants come to occupy various strata of the financial power index, this ultimately generates more wealth and prosperity for all [23].

\section{Islamic financial instruments are promising and} require development in Kazakhstan

Kazakhstan, the second-largest republic among the former Soviet Union countries, is also the ninth-largest country in the world, roughly the size of Western Europe. The economic situation of the country has been reorganized so that it is one of the large economies in Central Asia: with a GDP of 170.5 billion US dollars and foreign trade turnover of 93.5 billion US dollars, Kazakhstan is ranked 28th in the World Bank Business development ranking (out of 190 members), as well as considered to be among the most improved economies. ${ }^{1}$

The emergence of Islamic finance in Kazakhstan can be traced back to the 1990s. Kazakhstan became a member of the Islamic Development Bank in 1998, after which the first IDB Regional Office in Central Asia and CIS was opened in Almaty. The IDB began to play an essential role in the introduction and development of Islamic finance in Kazakhstan, while the projects and initiatives undertaken by the IDB Group have allowed the country to overcome some major economic and social challenges.

It should be mentioned here that over the eight-years from 2010 to 2017, Islamic banking in Kazakhstan grew six-fold (599\%). However, the volume of assets of Islamic banks is less than 1\% of all assets of the banking system. ${ }^{2}$ Nowadays, the domestic market of Islamic finance is presented by two Islamic banks (Al Hilal Bank and Zaman Bank), the Islamic leasing companies Ijara and AlSaqr Finance, and Mudaraba capital company [24].

However, the future of Islamic finance is promising for several reasons. Firstly, the majority of Kazakhstan's population of 18 million 514 thousand, is Muslim, at about $70.2 \%$ according to official figures, and there are 2404 mosques and 12 Muslim religious educational institutions. ${ }^{3}$

Kazakhstan is also considered a regional financial hub, and the development of Islamic finance is one of the six pillars of Astana International Financial Centre. The country is thus an attractive platform for the development of Islamic finance in the region. The AIFC plans to become a regional Islamic finance hub for the countries of Central Asia and the CIS by providing specialized infrastructure, legal and tax regimes, and opportunities for professional development.

However, despite all of the information presented above, Islamic finance remains 1 www.traidingeconomics.com - available at: https:// tradingeconomics.com/kazakhstan/indicators

2 www.nationalbank.kz - official web-site of the National Bank of the PR, available at: https:// nationalbank.kz/?docid $=3009 \&$ switch $=$ english

3 www.data.worldbank.org - official web-site of data World Bank. available at: https://data.worldbank.org/ country/KZ 
unfortunately underdeveloped in Kazakhstan. If its enormous potential in the region is to be realized, there are some issues and challenges that have to be overcome, particularly as regards Islamic social finance tools, which have never been considered and accepted as possible drivers of Islamic finance development.

In terms of Islamic social instruments, zakat and waqf systems are not governed by a special regulatory framework standardizing their administration. Thus, issues have arisen including disorganized administration and the ineffective collection and distribution of zakat and waqf funds. Nevertheless, charity relations are regulated by a secular legal framework. Another challenge needing to be addressed concerns the insufficient number of zakat and waqf institutions. There is no doubt that one of the major problems in Islamic finance development is the lack of literacy about Islamic social finance instruments, as well as Islamic finance in general. Most of the population have the impression that Islamic finance is not grounded in economic relations and is based only on charity and free financing, without any administration and profit-sharing. For example, people have strong and clear beliefs that Zakat is not obligatory and has to be paid only in Ramadan and only by individuals. There is thus the enormous potential for Islamic finance to be more transparent and developed further to enable it to achieve its full potential in the region.

There are many directions for the use of zakat funds and beneficiaries, such as financial assistance to low-income groups, providing materials and resources for religious education, endowing scholarships for students in religious schools, and paying the salaries of religious leaders. In practice, zakat funds are used for the salaries of Imams and repairing mosques.

Furthermore, the absence of official and centralized information regarding the amount of the zakat, along with a lack of transparency regarding funds, leads to a lack of institutional trust from the public. It is thus a fact that the population prefers to give to poor and needy people directly.

\section{Methodology and analytical approach}

As has been argued in previous sections of this paper, there is scope to overcome the issues and challenges faced by all stakeholders, including the government, AIFC, policy-makers, and Islamic finance scholars and institutions and population.

In an attempt to provide recommendations for addressing the challenges in the country, qualitative analysis via a survey has been conducted among the population. A stratified sample of 1252 respondents from different areas (urban and rural) of Kazakhstan and various age groups were surveyed. Certain criteria were set to ensure that each participant provides reliable and sufficient information. The statistical techniques were used during the process to attain the profile and behavioral pattern of the participant. The data were analyzed using descriptive statistics in the form of frequency and percentage in the computation of the variables.

The participant must be 18 years or older as questions require mature answers that stem from knowledge and experience. The research instrument did not aim to identify gender as both genders have equal, political, economic, social, internal, internal and other rights by the country Constitution.

The age distribution of the respondents was divided into 4 groups: 18-30, 30-44, 45-63 and 64 - older. The reason for considering last age group is that the retirement age for both genders in the country -63 . There is a limitation of the last age group respondents of the study, only $2,5 \%$ of the respondents are under 64 years old. This age group is not an active user of Internet resources through which the questionnaire was disseminated among respondents. The distribution of respondents of the study is - 18-30 age group - 39.5\%, 30-44 age group - 29\% and $45-63$ age group - 29\%. As can be seen from the data below, the young age group was more active during the study, as the survey done by the method of collecting sociological information, based on the use of Internet technologies - internet or a web survey.

The answer to the question to how often do respondents do charity is distributed as follows: 28.4\% (355) answered - monthly, 19.2\% (240) answered - once in three months, $15.8 \%$ (198) do charity every half-year, while $30.6 \%$ (383) of respondents do charity once a year on Ramadan. In general, we can say that the majority of the population takes part in Islamic charity events, like Qurban, Ramadan. Only 6.1\% (76) of respondents never do charity, they do not belong to the considering denomination or do not have extra funds for charity.

The annual average spending on charity was requested to identify the level of social responsibility of the respondents as well as the average amount of savings or investment (zakatable assets). More than half of the respondents 53.3\% (667) spend on charity less than 100 US dollars per year. $28.8 \%$ spend on charity from 100 to 500 US dollars, and only 40 respondents or $3.2 \%$ make donations over 1000 US dollars. Zakat is the mandatory and minimum amount of funds that a Muslim is obliged to pay. More than half of people have less than 4000 US dollars zakatable assets (savings, gold, investment), as the rate of zakat depend on the nature of origin the zakatable items is $2.5 \%$ by Kahf and AAOIFI Standards and zakat is the required minimum of the donations of 
Muslim [25]. The annual spending for charity by respondents reflects population segmentation by income [26]. The majority does not have sufficient funds to make large donations. It is difficult to show the delivery data since the donation system does not have centralized open data.

$67.2 \%$ (841) of respondents aware of the difference between main Islamic social finance tools Zakat and Sadaqah. Most people distinguish between Islamic social finance tools and are familiar with the purposes of these donation forms. However, the fundamental concept of Shariah - riba is unknown to most respondents, 715 of respondents $57.1 \%$ do not have an understanding of the concept of riba (interest) in Islamic finance, only $19.2 \%$ know the riba concept good and $23.6 \%$ satisfactorily. The awareness on Waqf, that is understanding of the existence of the institution of waqf, the purpose of Waqf in Islamic finance, the role of Waqf in poverty alleviation, is less than $6 \%$, consequently, about $94 \%$ of the people do not well the Waqf concept and the role of it in the developing Islamic finance. As a result, 990 of respondents, $79 \%$ answered that they need an explanation about the function of Waqf. There is a problem of awareness of the Waqf In Kazakhstan and, accordingly, the problem of underdevelopment of this direction, including the opacity of funds, the functioning and distribution of funds is not open and, as a result, there is no market for Islamic securities.

This study indicates that $44.1 \%$ of the respondents know about Islamic social finance tools as Zakat, Sadaqah and Waqf from family and friends, $34.3 \%$ from internet and social media, while just $5 \%$ studied on courses and training and $8 \%$ participated in conferences and forums on Islamic finance. According to the survey results, knowledge about Islamic finance is informative and superficial and only a small number of the population have a deep knowledge of Islamic finance instruments.

$71.3 \%$ of respondents do charity directly to needy people, while $26.2 \%$ donate through mosques, it is explained by the inability to trace the donation, the absence of a centralized system of charity in the country and the mistrust of intermediaries, mistrust to spiritual institutions.

It should be noted that $63.8 \%$ of the people ready to use a charity application where you could choose the direction of the charity, see the result of the donation. Thus, when organizing a transparent system for the functioning of Islamic social Finance, more than half of the respondents are ready to use modern technologies in the form of applications.

The World Health Organization (WHO) has officially declared the SARS-CoV-2 outbreak a public health emergency of international concern on January 30, 2020, and a global pandemic on March 11, 2020. WHO has called on countries for strict social distancing and quarantines, measures to prevent the spread of the virus and protect public health [27]. Despite fragmented international efforts to contain the transmission, SARS-CoV2 has spread to 213 countries, resulting in more than 5 million cases and nearly 400,000 deaths since its official detection in Wuhan, China in December 2019 [28]. As the pandemic spread throughout the world, countries have taken drastic measures to protect their citizens. the coronavirus pandemic was not spared in Kazakhstan and the emergency has been declared in the country on March 16, 2020. These measures focused on striking a delicate balance between limiting the spread of the virus from person to person and keeping economic activity. It was an impossible balance, although the timing of these measures proved to be critical for both public health and the spread of SARS-CoV2, and the impact on the country's economics. The early isolation and strict compliance with the rules were the most effective strategies to contain the spread of the virus [27]. In this regard, many industries and companies were closed in Kazakhstan, which led to a decline in economic activity and, consequently, a decrease in the income of the population. It should be noted that, in June-July, the situation with the spread of coronavirus in Europe has significantly stabilized, Kazakhstan at this time had a peak incidence, reported a massive daily increase in the number of cases of infection and ranked first in the world in terms of morbidity. There were problems with testing, lack of ventilators, medicines. At the same time, there was restructuration in charity in the country, which was aimed at medical equipment, support for doctors, for families of deceased doctors, the purchase of ambulances, even the assistance in food for families who suffered Covid-19. The pandemic has exposed existing problems, hitting especially the low-income segments of the population. The pandemic effect for the charity was negative, demand for aid has increased, while funding has suffered. The pandemic led to a drop in donations from the population and emphasized the importance of large philanthropists. ${ }^{4}$ The total large philanthropists' charity amount against the pandemic in Kazakhstan was about 15221.00 million tenge by some estimates (Table 1).

As can be seen from the table above large companies of the country have spent significant amounts of money in the fight against the pandemic. However, there is unavailable any statistical data of charity amount in general in the country and the share of decrease as a result of the pandemic.

4 Coronavirus and charity, [electronic source] URL: https://inbusiness.kz/ru/last/koronavirus-i-blagotvoritelnost (date: 24.08.2020) 
Table 1 - Large philanthropists' charity to fight the pandemic in Kazakhstan

\begin{tabular}{|c|c|c|}
\hline & Philanthropists & Charity sum, million tenge \\
\hline 1 & Foundation of the First President of the Republic of Kazakhstan & 200 \\
\hline 2 & Bulat Utemuratov Foundation & 2000 \\
\hline 3 & Verny Kapital & 420 \\
\hline 4 & "Halyk" Charitable Foundation & 5500 \\
\hline 5 & BI Group & 100 \\
\hline 6 & KAZ Minerals group & 2200 \\
\hline 7 & "Sabi" Charitable Foundation & 220 \\
\hline 8 & Astana Group & 222 \\
\hline 9 & ERG Group & 100 \\
\hline 10 & SberBank & 50 \\
\hline 11 & Serik Tolmasov Foundation & 25 \\
\hline 12 & Bazis-A Corporation & 2 \\
\hline 13 & Beeline & 1600 \\
\hline 14 & Universal Energy Qazaqstan & 50 \\
\hline 15 & Foundation "Beautiful Children of Kazakhstan" & 50 \\
\hline 16 & International company Kusto Group & 1058 \\
\hline 17 & Charity Foundation "Positive Umit" & 174 \\
\hline 18 & "Shugyla" Public Foundation & 450 \\
\hline 19 & BankCenterCredit & 100 \\
\hline 20 & "Green energy" company & 600 \\
\hline 21 & Karaganda Ferroalloy Plant & 100 \\
\hline \multicolumn{3}{|c|}{ Note - Compiled by the author by the source $\left[{ }^{5}\right]$} \\
\hline
\end{tabular}

For investigating the dependence of the charity condition and the possible impact of the pandemic on Islamic social finance tools, the survey of respondents was conducted, from January till August 2020. As a result, 1,252 responses were received, of which 454 responses were received after the announcement of the state of emergency in Kazakhstan.

In this regard, we conducted two correlation analyses to reflect the dependence of indicators before the emergency and after the emergency was declared. There has been applied SPSS (Statistical Package for the Social Sciences) statistics and survey-based indicators. The following responses were selected as indicators:

1. Age (Question 1)

2. How often do you do charity? (Question 2)

3. How much do you spend on charity per year? (Question 3)

\footnotetext{
5 Charity-2020: how entrepreneurs helped Kazakhstan in the covid-year, [electronic source] URL: https:// forbes.kz//life/hero/blagotvoritelnost-2020 kak predprinimateli_pomogali_kazahstanu_v_kovidnom godu/? (date: 21.12 .2021$)$
}

4. Would you use a charity application where you could choose the direction of the charity, see the result of the donation? (Question4)

5. Do you aware of the differences between Islamic social finance tools Zakat and Sadaqah? (Question 5)

The descriptive statistics for the variables, after the Emergency was declared, used in this study are presented in Table 3. 
Table 2 - Correlations between variables

\begin{tabular}{|c|c|c|c|c|c|c|}
\hline & & Q1 & Q 2 & Q 3 & Q 4 & Q 5 \\
\hline \multirow[t]{3}{*}{ Question 1 } & Pearson's $r$ & 1 & $279^{* *}$ &, $319^{* *}$ &, 003 &, $071^{*}$ \\
\hline & 2-sided statistical significance & &, 000 &, 000 & ,911 &, 012 \\
\hline & $\mathrm{N}$ & 1252 & 1252 & 1252 & 1252 & 1252 \\
\hline \multirow[t]{3}{*}{ Question 2} & Pearson's $r$ &, $279^{* *}$ & 1 &, $208^{* *}$ &, $058^{*}$ &, $063^{*}$ \\
\hline & 2-sided statistical significance &, 000 & &, 000 &, 041 &, 027 \\
\hline & $\mathrm{N}$ & 1252 & 1252 & 1252 & 1252 & 1252 \\
\hline \multirow[t]{3}{*}{ Question 3 } & Pearson's $r$ & $319^{* *}$ & ,208 & 1 &, $156^{* *}$ &, $196^{* *}$ \\
\hline & 2-sided statistical significance & 000 & 000 & &, 000 &, 000 \\
\hline & $\mathrm{N}$ & 1252 & 1252 & 1252 & 1252 & 1252 \\
\hline \multirow[t]{3}{*}{ Question 4} & Pearson's $r$ & ,003 &, $058^{*}$ &, $156^{* *}$ & 1 &, $150^{* *}$ \\
\hline & 2-sided statistical significance & ,911 & ,041 &, 000 & &, 000 \\
\hline & $\mathrm{N}$ & 1252 & 1252 & 1252 & 1252 & 1252 \\
\hline \multirow[t]{3}{*}{ Question 5} & Pearson's $r$ &, $071^{*}$ &, $063^{*}$ &, $196^{* *}$ &, $150^{* *}$ & 1 \\
\hline & 2-sided statistical significance &, 012 &, 027 &, 000 &, 000 & \\
\hline & $\mathrm{N}$ & 1252 & 1252 & 1252 & 1252 & 1252 \\
\hline $\begin{array}{l}* * \text {. Correlati } \\
* \text {. Correlatio } \\
\text { Note }-\end{array}$ & $\begin{array}{l}\text { statistical significance on } 0,01 \text { ( } \\
\text { tatistical significance on } 0,05 \text { ( } 2 \\
\text { urce: Authors' estimations }\end{array}$ & & & & & \\
\hline
\end{tabular}

Table 3 - Correlations between variables after the announcement state of Emergency

\begin{tabular}{|c|c|c|c|c|c|c|}
\hline & & Q1 & Q 2 & Q 3 & Q 4 & Q 5 \\
\hline \multirow[t]{3}{*}{ Question 1 } & Pearson's $r$ & 1 &, $316^{*}$ &, $093^{* *}$ & 053 &, 056 \\
\hline & 2-sided statistical significance & & 000 &, 047 & ,264 & ,230 \\
\hline & $\mathrm{N}$ & 454 & 454 & 454 & 454 & 454 \\
\hline \multirow[t]{3}{*}{ Question 2} & Pearson's $r$ &, $316^{* *}$ & 1 &, 000 & 000 & ,007 \\
\hline & 2-sided statistical significance &, 000 & &, 000 &, 041 &, 027 \\
\hline & $\mathrm{N}$ & 454 & 454 & 454 & 454 & 454 \\
\hline \multirow[t]{3}{*}{ Question 3} & Pearson's $r$ &, $093^{*}$ &, $174^{* *}$ & 1 &, $337^{* *}$ &, $227^{* *}$ \\
\hline & 2-sided statistical significance &, 047 &, 000 & &, 000 &, 000 \\
\hline & $\mathrm{N}$ & 454 & 454 & 454 & 454 & 454 \\
\hline \multirow[t]{3}{*}{ Question 4} & Pearson's $r$ &, 053 &, $216^{* *}$ &, $337^{* *}$ & 1 &, $156^{* *}$ \\
\hline & 2-sided statistical significance &, 264 & ,000 &, 000 & &, 001 \\
\hline & $\mathrm{N}$ & 454 & 454 & 454 & 454 & 454 \\
\hline \multirow[t]{3}{*}{ Question 5} & Pearson's $r$ &, 056 &, $126^{* *}$ &, $227^{* *}$ &, $156^{* *}$ & 1 \\
\hline & 2-sided statistical significance & ,230 &, 007 &, 000 &, 001 & \\
\hline & $\mathrm{N}$ & 454 & 454 & 454 & 454 & 454 \\
\hline $\begin{array}{r}* * \text {. Correlati } \\
* \text {. Correlatio } \\
\text { Note - }\end{array}$ & $\begin{array}{l}\text { statistical significance on } 0,01 \\
\text { tatistical significance on } 0,01 \text { ( } 2 \\
\text { urce: Authors' estimations }\end{array}$ & & & & & \\
\hline
\end{tabular}

\section{Results and Discussion}

The highest significance was shown by the relationship between such indicators as «age» and «how often do you do charity?» $(0.316, \mathrm{p}=0.01)$. It should be noted that after the announcement of the emergency, the impact of mobile apps on the amount of charity increased. This confirms the correlation coefficient between the indicators «How much do you spend on charity per year?» and «Would you use a charity application where you could choose the direction of the charity, see the result of the donation?» it was more significant than before the emergency, amounting to 0.337 ; $\mathrm{p}=0.01$. Also, it is important to note that on this 
Ramadan all commercial banks in the country have launched the Sadaqah and Zakat payment service via the Bank's mobile applications.

Particular attention is drawn to the correlation coefficient between such indicators as "Age» and «How much do you spend on charity per year?» After the announcement of the state of emergency, this indicator became insignificant, whereas, before the announcement of the state of emergency, it was $0.187^{* *} ; p=0.01$. Therefore, if earlier people were more engaged in charity with age (older people spend more than younger), then after the state of emergency was declared, the amount of charity did not depend on age.

It is also important to note that after declaring a state of emergency the correlation coefficient between the indicators «How often do you do charity?» and «Would you use a charity application where you could choose the direction of the charity, see the result of the donation?» was significant, making of $0.216, p=0.01$, because before the Emergency, these figures did not correlate. This suggests that people are starting to use mobile apps more often for charity.

After the Emergency in the country the relationship between «How much do you spend on charity per year?» and « Would you use a charity application where you could choose the direction of the charity, see the result of the donation?» with such an indicator as «Do you aware of the differences between Islamic social finance tools Zakat and Sadaqah?» it became more significant, amounting to $0.227^{* *} ; \mathrm{p}=0.01$, and $0.135^{* *}$; $\mathrm{p}=0.01$, respectively. This analysis suggests that after the emergency was declared, the popularity of Zakat and Sadaqah has increased and the charity has grown through the applications.

From the qualitative survey-based data results, it can be concluded that respondents mostly do charity once a year during Ramadan and only 76 respondents from 1252 do not do charity, this approved the authors' suggestions of the necessity of promoting zakat as obligatory payment for the Muslim population. More than half of respondents spend on charity less than 100 US dollars, this fact defines the low level of the population's savings. It is identified that more than half of the respondents do not aware of the main Islamic financial concept - riba. This allows us to conclude that Islamic social finance is developed at the individual level and poorly developed at the level of financial institutions, banks and investment funds. If to turn to the waqf institutions system, about ninths part of respondents do not aware of this system and need the explanation. That can be explained by the absence of waqf institutions in the country as a result of the absence legislative framework for it, despite the huge potential. The majority of respondents do charity directly to needy people, as they have mistrust to the spiritual institutions, however people ready to use special transparent applications and platforms for doing charity. From the results of the research, the authors prepared recommendations for overcoming the issue and develop Islamic social finance in the country.

\section{Conclusion}

Islamic finance and sustainable development are increasingly converging, and Islamic social finance tools could be both a resource and a solution for solving sustainability issues during and after the pandemic period.

To overcome the challenges facing the development of Islamic finance in Kazakhstan, as well as in the region, it is primarily necessary to create a specific legislative framework. Creating a Zakat and Sadaqah database in the form of a unified data center and optimizing online zakat platforms (as $77 \%$ of the population are internet users) will increase the total levels of trust in Islamic social finance and impact the growth of Islamic financial inclusion accordingly. However, the most important issues are the promotion of Islamic social finance tools among the population and business community, along with the improvement of Islamic financial literacy. The results of the study showed that people do charity and aware of Sadaqah and Zakat on an individual level and know about these tools of Islamic finance from the family and friends. The time when biological (Covid-19) and economic crisis come together demonstrated that, the need for doing charity has increased, but the number of needy people has grown too. 8.21 million of the population made an application to the social payments due to loss of income during the state of emergency, that is about $89 \%$ of the total economically active population. ${ }^{6}$

Islamic finance will make instrumental contributions towards financial inclusion and sustainability based on the following:

- Although Islamic social tools have been never considered as a driver for Islamic finance development in Kazakhstan, the worth of total assets under global Waqf exceeds 1 trillion US dollars [17].

- The justifiable scepticism of zakat payers and waqf donors can be dealt with using advances in technology. Zakat payments can be calculated and made using smart applications that would

\footnotetext{
6 More than 8 million Kazakhstanis have applied for assistance in connection with the loss of income during the emergency, [electronic source] URL: https:// inbusiness.kz/ru/last/bolee-8-mln-kazahstancevpodali-zayavku-na-poluchenie-pomoshi-v-svyazi-spoterej-dohodov-v-period-chp (date: 20.04.2020)
} 
present options to payers based on their personal preferences.

- Islamic social finance can be promoted as a value-based finance system and an investment that would strengthen financial inclusion in the region by AIFC (one of the six pillars).

- The adaptation of best international practice, considering the best foreign experience of implementing legal frameworks by adapting to the domestic market, and the use of financial technology tools to increase both transparency and the use of these tools, is strongly recommended.

- The problem of poverty can be partially solved by ensuring the transparency of charitable funds.

- It is possible to solve pointwise the problem of access to drinking water by using the tools of social Islamic finance since every 10 in the country does not have access to drinking water.

Covid-19 affected every aspect of the life of almost all the world's population. It should be understood that in the face of fears of economic recession and collapse, every citizen must participate in understanding and mutual assistance. Forced isolation and the situation in the world against the backdrop of the pandemic have shown how important it is to be indifferent. This is evidenced by the increase in the dependence of indicators as age and frequency of donations (0.279 and 0.316 , respectively). Also, it should be noted an increase in the correlation between the rates of use of applications for donations and their frequency, 0.337 versus 0.156 . This is confirmed by the fact that, with the increase in Internet usage and the transition to online, the activity of Internet donation applications has also been affected.

However, the crisis reaffirmed a sustained and strong impact on the health system, economics, government and society in general. There is a need for transparent distribution of finance, as in the practice of countries where Islamic social finance is developed and introduced into the financial system. As well as activation of charitable foundations and simplification of the procedure for paying sadaqah and zakat.

\section{References}

1. Kheifets B. A. A new wave of the global debt crisis: risks are increasing // Economic issues. - 2017. N12. - P. 81-95. DOI 10.32609/0042-8736-2017-12-8195

2. Nicola M. et al., The socio-economic implications of the coronavirus pandemic (COVID-19): A review // International Journal of Surgery. - 2020. N 2(78). - P. 185-193. DOI 10.1016/j.ijsu.2020.04.018

3. Azmi S./ Global Islamic Finance Report. Artificial intelligence and innovation in Islamic finance - London, 2019.- 264 p.
4. Islamic Finance Outlook 2020 / Standard \&Poor's Global - UAE, Dubai, 2020. - 111p.

5. 2012 Global Sustainable Investment Review 2012/ Global Sustainable Investment Alliance (GISA) Australia, 2013.

6. Global sustainable investment review 2018/ Global Sustainable Investment Alliance (GISA) Australia, 2019.

7. Hassan M. K., Aliyu S., Huda M., and Rashid M. A survey on Islamic Finance and accounting standards // Borsa Istanbul Review. - 2019. - N 2. P. 1-13. DOI 10.1016/j.bir.2019.07.006

8. Chapra M. U. The Nature Of Riba In Islam // Millah. - 2008. - №1(8). DOI 10.20885/millah.vol8.iss1. eng.art5

9. Usman M., Qamar Jibran M. A., Amir-ud -Din R. and Akhter W. Decoupling hypothesis of Islamic stocks: Evidence from copula CoVaR approach // Borsa Istanbul Review. - 2019. - N 19. - P. - 56-63. DOI 10.1016/j.bir.2018.09.001

10. Mirakhor A. and Iqbal Z. An Introduction to Islamic Finance: theory and practice. -Singapore: John Wiley \& Sons (Asia) Pte. Ltd., 2015. - 410 p.

11. Hassan M. and Shirazi N. S. Social tax and transfers for poverty alleviation: a case for low- and middle- income countries // Handbook of Empirical Research on Islam and Economic Life. - 2017. - P. 253272.

12. Islamic Finance Qualification ( IFQ) / Chartered Institute for Securities \& Investment. - 8th ed. London: CISI. - 2018. - 280 p.

13. Tahiri Jouti A. An integrated approach for building sustainable Islamic social finance ecosystems // ISRA International Journal of Islamic Finance. - 2019. №2 (11). - P. 246-266. DOI 10.1108/IJIF-10-2018-0118

14. Al Qardawi Y. Fiqh al zakah: A comparative study of zakah, regulations and philosophy in the light of Quran and Sunnah. Valume 2. - Jeddah: Scientific Publishing Centre King Abdulaziz University, 1999. $345 \mathrm{p}$.

15. Obaidullah M. and Shirazi N. S. IRTI Islamic Social Finance Report 2017. - Islamic Research and Training Institute, 2018.

16. Obaidullah M. and Shirazi N. S. Islamic Social Finance report 2014. - Islamic Research and Training Institute, 2015.

17.Azmi S. Global Islamic Finance Report. Key Highlights - London, 2018.- 277 p.

18. Islamic Research and Training Institute. Waqf and Zakat:solidarity-based financing for sustainable development. - Kingdom of Saudi Arabia, Jeddah, 2014.

19. United Nations Office for the coordination of Humanitarian Affairs. Global Humanitarian overview 2020 - Geneva: OCHA, 2019.

20. Moyer J. D. and Hedden S. Are we on the right path to achieve the sustainable development goals? // World Development - 2020 - N 127. DOI 10.1016/j. worlddev.2019.104749

21. Muhammad S. A. and Saad R. A. Moderating Effect of Attitude toward Zakat Payment on the Relationship between Moral Reasoning and Intention to Pay Zakat // Social and Behavioral Sciences. - 2016 N 219 - p. 520-527. DOI 10.1016/j.sbspro.2016.05.029 
22. Azretbergenova G. Zh., Syzdykova A. O., Saparova A. A., Zhetybaev Zh. K.assessment of Islamic finance in Kazakhstan and opportunities for Industry Development // Economics: Strategy and practice. 2020. - No. 4 (15) - p. 89-100.

23. Sagiyeva R. K. and Kuanova L. A. Analysis of Islamic Finance development in Kazakhstan : overview and prospects // Экономика: стратегия және практика. - 2019. - N 3 (14) - p. 39-48.

24. Sagiyeva R. K. and Kuanova L. A. Islamic finance in Kazakhstan: adaptation of foreign experience // The Journal of economic research and business administration. - 2019. - N 1 (127) - p. 56-65.

25.Kahf M. Lessons in Islamic Economics. Volume 2. - Jeddah: Islamic Research and Training Institute, 1998. $-343 \mathrm{p}$.

26. Accounting and Auditing Organization for Islamic Financial Institutes. Sariah Standards. - Manama: AAOIFI, 2015. - 563 p.

27. Guzzetta G. et al. The impact of a nationwide lockdown on COVID-19 transmissibility in Italy // Quantative Biology. Cornell University - 2020 - N 4. available at: https://arxiv.org/abs/2004.12338

28. Cheng S. O. and Khan S. Europe's response to COVID-19 in March and April 2020 - A letter to the editor on 'World Health Organization declares global emergency: A review of the 2019 novel coronavirus (COVID-19)' // International Journal of Surgery. - 2020 - № 4 (78) - pp. 3-4. DOI 10.1016/j.ijsu.2020.04.011

\section{Список использованных источников}

1. Хейфец Б. А. Новая волна глобального долгового кризиса: риски возрастают // Вопросы экономики. - 2017. - № 12. - С. 81-95.

2. Никола М. и др. Социально-экономические последствия пандемии коронавируса (COVID-19): обзор // Международный журнал хирургии. - 2020. № 2(78). - С. 185-193.

3. Азми С. /Глобальный отчет по исламским финансам. Искусственный интеллект и инновации в исламских финансах - Лондон, 2019.- 264 с.

4. Перспективы исламских финансов на 2020 год / Standard \&Poor’s Global - ОАЭ, Дубай, 2020. $-111 \mathrm{c}$.

5. Обзор глобальных устойчивых инвестиций 2012 г. / Всемирный альянс устойчивых инвестиций (GISA) - Австралия, 2013 г.

6. Обзор глобальных устойчивых инвестиций 2018 / глобальный альянс по устойчивым инвестициям (GISA) - Австралия, 2019.

7. Хасан М. К., Алию С., Худа М. и Рашид М. Обзор исламских финансов и стандартов бухгалтерского учета // Borsa Istanbul Review. - 2019. - №2. - C. 1-13.

8. Чапра М. У. Природа Рибы В Исламе // Милла. - 2008. - № 1(8).

9. Усман М., Камар Джибран М. А., Амируд- Дин Р. и Ахтер У. Гипотеза развязки исламских акций: доказательства CoVaR подхода // Borsa Istanbul Review. - 2019. - № 19. P. - 56-63.
10.. Мирахор А. и Икбал 3. Введение в исламские финансы: теория и практика. -Сингапур: John Wiley \& Sons (Asia) Pte. OOO, 2015. - 410 c.

11. Хасан М. и Ширази Н. С. Социальный налог и трансферты для борьбы с бедностью: пример для стран с низким и средним уровнем дохода // Справочник по эмпирическим исследованиям ислама и экономической жизни. - 2017. - С. 253-272.

12.Квалификация исламских финансов ( IFQ) / Chartered Institute for Securities \& Investment. - 8-e изд. Лондон: CISI. - 2018. - 280 с.

13.Тахири Джути А. Комплексный подход к построению устойчивых экосистем исламских социальных финансов // ISRA International Journal of Islamic Finance. - 2019. - № 2 (11). - C. 246-266.

14.Аль-Карадави Ю. Фикх аль-зекет: Сравнительное изучение зекета, правил и философии в свете Корана и Сунны. Том 2. - Джидда: Научно - издательский центр Университета Короля Абдулазиза, 1999. - 345 с.

15. Обайдулла М. и Ширази Н.Ш. IRTI Отчет по Исламским социальным финансам 2017. Исламский научно-исследовательский и учебный институт, 2018.

16.Обайдулла М. и Ширази Н.Ш. Отчет об исламских социальных финансах за 2014 год. Исламский научно-исследовательский и учебный институт, 2015.

17.Азми С. /Отчет Глобальных Исламских Финансов. Ключевые моменты. - Лондон, 2018.277 c.

18.Исламский научно-исследовательский и учебный институт. Вакф и закят:финансирование устойчивого развития на основе солидарности. Королевство Саудовская Аравия, Джидда, 2014.

19.У Уравление Организации Объединенных Наций по координации гуманитарных вопросов. Глобальный гуманитарный обзор 2020 года Женева: 2019.

20.Мойер Дж.Д. и Хеден С. Находимся ли мы на правильном пути к достижению целей устойчивого развития? // Мировое развитие - 2020 - № 127.

21. Мухаммад С.А. и Саад Р.А. Умеряющее влияние отношения к выплате Закята на взаимосвязь Моральных рассуждений и намерения платить Закят // Социальные и поведенческие науки. - 2016. - № 219 - с. $520-527$.

22. Азретбергенова Г.Ж., Сыздыкова А.О., Сапарова А.А., Жетыбаев Ж.К. Оценка исламского финансирования и возможности развития отрасли в Казахстане / / Экономика: стратегия и практика. 2020. - № 4 (15) - C. 89-100.

23.Сагиева Р.К. и Куанова Л.А. Анализ развития исламских финансов в Казахстане : обзор и перспективы // Экономика: стратегия және практика. - 2019. - № 3 (14) - c. 39-48.

24.Сагиева Р.К. и Куанова Л.А. Исламские финансы в Казахстане: адаптация зарубежного опыта // Вестник КазНУ: экономическая серия 2019. — № 1 (127) — c. 56-65.

25.Каф М. Уроки исламской экономики. Том 2. - Джидда: Исламский научно-исследовательский и учебный институт, 1998. -343 с. 
26.Организация бухгалтерского учета и аудита Исламских финансовых институтов. Нормы шариата. - Манама: ААОИФИ, 2015. - 563 с.

27.Гузетта Г. и др. Влияние общенациональной блокировки на трансмиссивность COVID-19 в Италии // Квантовая биология. Корнельский университет - 2020. - № 4. Доступно по адресу: https://arxiv.org/abs/2004.12338
28. Ченг С.О. и Хан С. Ответ Европы на COVID-19 в марте и апреле 2020 года - Письмо редактору на тему «Всемирная организация здравоохранения объявляет глобальную чрезвычайную ситуацию: обзор нового коронавируса 2019 года (COVID-19)» // Международный журнал хирургии. - 2020. - № 4 (78) - с. 3-4.

\section{Information about the authors}

Nasim Shah Shirazi - professor, Ph.D, College of Islamic Studies, Hamad Bin Khalifa university, Doha, Education city, 34110, Qatar, nshirazi@hbku.edu.qa

Laura Aibolovna Kuanova - corresponding author, 3d year PhD student, Al-Farabi Kazakh national university, Higher School of Economics and Business, Almaty, Al-Farabi av., 050040, Kazakhstan, Director of Islamic finance centre, kuanova.laura@kaznu.kz

Aziza Serikovna Zhuparova - acting associate professor, Ph.D, Al-Farabi Kazakh national university, Higher School of Economics and Business, Almaty, Al-Farabi av., 050040, Kazakhstan, aziza_z@mail.ru

\section{Авторлар туралы мәліметтер}

Ширази Н.Ш. - профессор, Исламдық зерттеулер Колледжі, Хамад Бин Халифа университеті, Доха, Эдукейшн сити, 34110, Қатар, nshirazi@hbku.edu.qa

Қуанова Л.А. - хат-хабаршы авторы, 3 курс докторанты, Экономика және бизнес жоғары мектебі, Әл-Фараби атындағы қазақ ұлттық университеті, Алматы, Әл-Фараби даңғылы, 050040, Қазақстан, Исламдық қаржы Орталығының директоры, laura_kuanova@mail.ru

Жұпарова А.С. - доцент м.а., Экономика және бизнес жоғары мектебі, Әл-Фараби атындағы қазақ ұлттық университеті, Алматы, Әл-Фараби даңғылы, 050040, Қазақстан, aziza_z@mail.ru 